\title{
Verzeichniss \\ der Herren, welche für den neunten Band Referate geliefert haben.
}

(Die Verantwortlichkeit für den Inhalt der Referate tragen die Herren Referenten. Die in Klammern gesetzten Chiffern bezeichnen die Uebersetzer der in fremder Sprache eingesandten Referate).

Herr Prof. August in Berlin.

- Dr. A ron in Charlottenburg.

A. Herr Prof. Mayer in Leipzig.

Mr.

- Prof. B a raniecki inWarschan. Bcki.

- Dr. Biermann in Berlio.

- Dr. Maynz in Ludwigslust.

Mz.

- Prof. Brill in München.

- Prof. Mitlag-Leffler in Hel. singfors.

M-L.

- Prof. Bruns in Berlio.

- Prof. Casey in Dublin.

Ba.

- Dr. F. Müller in Berlin.

M.

- Prof. Cayley in Cambridge.

B.

- Prof. Netto in Strassburg.

No.

- Dickstein in Warschau.

Csy.

- Prof. Neumann in Leipzig. Na.

- Prof. van Geer in Leiden.

Cly.

- Prof. Nõtber in Erlangen. Nr.

- Dr. Ohrtmann in Berlin. 0.

- Prof. Glaisber in Cambridge. Glr.

- Dr. Gram in Kopenhagen.

G.

- Prof. Oberbeck in Halle a.S. Ok.

- Dr. von Posse in Petersburg. P.

- Dr. Schemmel in Berlin. Schl.

Prof. Güntber in Ansbach. Gr.

- Dr. Hamburger in Berlin.

- Dr. Schlegel in Waren. Schg.

- Prof. Hoppe in Berlin.

Hr. - Dr. Schubert in Hamburg. Scht.

- Dr. Benno Klein in Berlin.

B. K.

- Prof. Felix Klein in München. Klo.

- Lazarus in Hamburg.

La. Prof. Lie in Christiania.

- Prof. Lüroth in Carisrube.

Ltb.

- Prof. Mansion in Gent.

Mn.

- Dr. Scbumann in Berlin. Schn.

- Prof. Stolz in Innsbruck. St.

- Prof. Studnička in Prag. Std.

- Prof. Sturm in Münster. Sm.

- Dr. Toeplitz in Breslau. T.

- Prof. Wangerin in Berlin. Wn.

Briefe und Zusendungen erbitten wir entweder durch Vermittelung der Verlagshandlung oder unter der Adresse:

Dr. C. Ohrtmann, Berlin SW., Markgrafenstr. 78. III. 
